\title{
Keyhole GTAW with Dynamic Wire Feeding Applied to Orbital Welding of 304L SS Pipes
}

\author{
Kauê Correa Riffel ${ }^{1}$ (D), Régis Henrique Gonçalves e Silva ${ }^{1}$, Giovani Dalpiaz², Cleber Marques $^{1}$, Mateus Barancelli Schwedersky ${ }^{1}$ \\ ${ }^{1}$ Universidade Federal de Santa Catarina - UFSC, Departamento de Engenharia Mecânica, Laboratório de Soldagem - LABSOLDA, Florianópolis, SC, Brasil. \\ 2 Petróleo Brasileiro S.A. - Petrobras, CENPES Centro de Pesquisa, Rio de Janeiro, RJ, Brasil.
}

How to cite: Riffel KC, Silva RHG, Dalpiaz G, Marques C, Schwedersky MB. Keyhole GTAW with dynamic wire feeding applied to orbital welding of 304L SS pipes. Soldagem \& Inspeção. 2019;24:e2418. https://doi.org/10.1590/0104-9224/SI24.18

\begin{abstract}
Currently, in the Brazilian Oil and Gas scenario the execution of welding processes for stainless steel consists mostly of manual applications, rendering hard any increase in productivity and repeatability. Therefore, the automation of this step allows several advances such as more reliable results, lower costs and healthier condition for welders. With the aim of developing automation for GTAW welding of these applications, experimental tests were carried out in a 304L stainless steel pipe laid out at $5 \mathrm{G}$ position. The samples were orbitally welded by GTAW with dynamic wire feeding process, using a robotic manipulator in two steps of $180^{\circ}$ in vertical down progression. The welding parameters and the stable condition obtained are discussed and the weld pool behavior during the root pass was online monitored by HDR (High Dynamic Range) videography. It was possible to reach high welding speed in the root pass, $50 \mathrm{~cm} / \mathrm{min}$ in a keyhole mode. The wire dynamic movement contributed to reach great process stability and robustness for all joint passes, from root to finishing. The macrographs and $\mathrm{x}$-ray analysis did not indicate discontinuities as porosity nor lack of fusion.
\end{abstract}

Key-words: Spools welding; TIP TIG; Stainless steel pipe welding; Root pass; Filling and finishing passes.

\section{GTAW Keyhole com Alimentação Dinâmica de Arame Aplicado à Soldagem Orbital de Tubos de Aço Inoxidável 304 L}

Resumo: Atualmente, no cenário brasileiro de óleo e gás a execução dos processos de soldagem para aços inoxidáveis consiste em sua grande maioria de aplicações manuais, dificultando qualquer aumento de produtividade e repetibilidade dos processos. Portanto, a automação desta etapa permite grandes avanços com resultados mais confiáveis, menores custos relacionados à mão-de-obra e condições de saúde mais favoráveis para os soldadores. Com o objetivo de automatizar a soldagem GTAW em aplicações orbitais, testes experimentais foram realizados em tubos de aço inoxidável $304 \mathrm{~L}$, posicionados na posição $5 \mathrm{G}$ de soldagem. As amostras foram soldadas pelo processo GTAW com alimentação dinâmica de arame, utilizando um manipulador robótico em 2 etapas de 180 na progressão vertical descendente. Os parâmetros de soldagem e a condição estável de soldagem obtidos foram discutidos e o comportamento da poça durante a soldagem do passe de raiz foi monitorado por videografia em HDR. Foi possível se alcançar alta velocidade de soldagem no passe de raiz, $50 \mathrm{~cm} / \mathrm{min}$ com o modo keyhole. O movimento dinâmico do arame contribuiu para alcançar-se grande estabilidade do processo e robustez na soldagem de todos os passes, da raiz ao acabamento. As macrografias e ensaios de raio-x realizados na junta não indicaram a presença de descontinuidades como poros e falta de fusão.

Palavras-chave: Soldagem de spools; TIP TIG; Soldagem de tubos de aço inoxidável; Passe de raiz; Passes de preenchimento e acabamento.

\section{Introduction}

The pipeline welding process is one of the main manufacturing steps for the oil and gas industry, whether in joining, coating or repair applications. In this context, the Gas Tungsten Arc Welding (GTAW) process is preferred under conditions in which quality requirements must be prioritized. However, due to the challenges in terms of reliability and robustness, the automation of the welding process is difficult to be implemented in real applications, with most operations still occurring manually. Thus, many works have been developed aiming the increase in stability, robustness and automating level for GTAW process, maintaining the quality characteristics by which the process is recognized. Richardson [1] and Ouyang et al. [2] provided examples which show the implementation of the automatic wire feeder in GTAW welding, in these cases the welder just controls the welding torch and the melt pool. Nowadays, this tool is widely used in numerous commercial equipment.

Received: 07 May, 2019. Accepted: 03 July, 2019

E-mails: kaue.riffel@posgrad.ufsc.br (KCR), regis.silva@ufsc.br (RHGS), giovani.dalpiaz@petrobras.com.br (GD), c.marques@posgrad.ufsc.br (CM), m.barancelli@ufsc.br (MBS) 
Similarly, Hori et al. [3] in order to increase the melting rate of the welding metal, presented a version of the GTAW with automatic feeding called pulsed hot wire, in which a preheating is applied to the wire through the passage of a pulsed electric current. Compared to conventional process, the hot wire technique also provides an increase in the welding speed, as presented by Anantha et al. [4].

Over recent years, a new approach of wire feeder has been used in which a forward and backward movement is applied to the feeder by an electromechanical system. This creates a similar behavior in welding wire's tip, increasing the process robustness and smoother metallic transfer [5]. Silva et al. [6] called this technique as dynamic wire feed. The authors show that during the forward and backward cycles, the wire undergoes intense accelerations and decelerations and reaches instantaneous speed higher than the average value, different from the traditional technique in which the wire is fed in a constant mode in a quasi-static regime. According to Riffel [7], during the wire's forward movement, it runs through the electric arc's isotherms with higher speed, preventing the formation of large droplets in its tip, which generates a higher robustness for out of position welding. The same technique was applied by Silva et al. [8] in a frequency of $1.25 \mathrm{~Hz}$, the objective was joining high-strength steel pipes for the oil and gas industry, the author also showed the possibility of increasing productivity in root pass welding for an automated welding. Silwal and Santangelo [9] using frequencies around $16 \mathrm{~Hz}$, reported a vibration in the filler metal that provided an extra force assisting in the transfer of the wire to the pool. In this case the authors used a drop transfer without the constant contact of the wire with the molten material as Chen et al. [10] characterized in their study. However, the authors restricted the experiments in bead on plate depositions, without evaluating the influence of the vibration in more critical situations, as an orbital welding for example.

The keyhole mode is recognized in the welding field as a high performance condition, which enables deeper penetration profiles, higher productivity through less joint machining and faster welding passes, compared to conventional mode [11]. Generally, the processes linked to keyhole mode are the LASER Beam Welding, Electron Beam Welding and the PAW (Plasma Arc Welding). In the case of arc welding processes, for PAW the main justifications are based on the greater arc constriction, plasma mechanic action and greater current density, which promotes a more localized pressure over the base material, provided by the recoil and stagnation pressure [12]. Jarvis and Ahmed [13] presented the possibility of reach the keyhole mode with the GTAW process either, under different mechanisms of keyhole formation compared to those for LASER and PAW. In this case, the author identified the electromagnetic force (Lorentz force) as the main responsible for the cavity formation, which must be capable to overcome the metalostatic pressure (inner pressure in a liquid due to gravity force) and the molten material's surface tension. Currents from $300 \mathrm{~A}$ are cited in the literature as capable to reach the keyhole mode, depending on the base material's physical properties and dimensions, in addition to the electrode sharpening angle. This last one changes the arc constriction and can generates significant differences in the plasma velocity [14].

Indeed, there is a great complexity in keyhole parametrization. The necessity of high current levels indicates the tendency of humping defects due to high arc pressure over the pool [15]. Thus, the input of filler material is necessary to mitigate problems related to humping, compensate gaps in the joint and undercuts prevention. Jarvis and Ahmed [13] used the filler wire inserted through the arc's fusion front, but this position promotes an extra barrier under the arc, formed of molten material, that avoids the arc action directly over the base material. The wire insertion from behind the arc (solidification front) can facilitate a more efficient fusion of the base material, as well as the keyhole's closing.

Jarvis and Ahmed [13] cited the necessity of gas mixtures with $\mathrm{Ar}+\mathrm{H}_{2}$ and $\mathrm{Ar}+\mathrm{N}_{2}$ to reach a stable keyhole, although Olivares et al. [15] showed suitable results using just pure Argon in $8 \mathrm{~mm}$ thick carbon steel plates. However, the keyhole application out of flat position is overly complex, because the interference of external forces as the gravity. Techniques to overcome the difficulties in the out of position keyhole application are presented as solutions. Li et al. [16] shown a PAW special technique called Double Stage, which has a specific wave format in pulsed current aiming to stabilize the keyhole crater out of the flat position. Therefore, commonly the keyhole is presented for pipes welding in a stationary way, in which the torch is kept static in flat position, and the pipe rotates around its own axis [11]. In automated orbital welding, executed at 5G position, the pipe remains static while a weld head conducts the welding torch along the circumference. In this case, the main problem faced in arc welding process is the change of the molten material behavior at different positions, as presented by Shirali and Mills [17]. At flat position the gravity force acts in the same direction as the electromagnetic force, facilitating the weld penetration. According to Figueirôa et al. [18], for the vertical position, there are two different behaviors that can occur, depending on progression of the welding torch, vertical up or vertical down. In the vertical up the pool tends to flow in the opposite direction in relation to torch movement, creating an optimal condition to increase the penetration, but a prejudicial situation to close the keyhole, for example. In other way, the vertical down creates a condition in which the gravity force produces a counter flow in relation to welding torch movement. This fact creates a barrier under the arc, which becomes a conductive condition to lower penetration. In the overhead position, the gravity force vector acts counter to the electromagnetic force vector, with a tendency to form a weld bead more convex in its face and concave at the root reinforcement.

Kou and Wang [19] presented a description of the main forces acting over the welding process, as well as them vector direction with the positions change in an orbital welding. The author branches the main forces into: gravity force; electromagnetic force; surface tension force; and drag force of the plasma jet. The behavior of the molten material is therefore dependent on the chemical composition of the weld metal. Then, stainless steels and nickel alloys are known to have low wettability when compared to conventional steels. This is due to the presence of alloying elements, such as $\mathrm{Cr}$ and Mo that have 
higher surface tension coefficient in melted state as shown by Xiao et al. [20]. Therefore, the behavior of the weld pool may be strongly influenced by the surface tension force. Shipilov et al. [21] the metal transfer must be kept constant and stable throughout the whole pipes's circumference, avoiding contamination of the electrode and consequent interruption of the process. In this way, the conjunction between keyhole mode and dynamic wire feeding maintains a stable metallic transfer and yields productivity benefits in the root pass for pipes/tubes orbital welding.

This work aims to develop an automated orbital welding methodology for stainless steel pipes, which are materials recognized for their difficult weldability. The methodology was based on the application of the GTAW keyhole process with dynamic wire feeding technique in the root pass, with higher travel speed, and GTAW with dynamic feeding for the filling passes. The phenomena and the behavior of GTAW during the keyhole welding of the root pass were identified through online HDR videography, as well as macrographs and X-ray tests for joint validation were highlighted and discussed.

\section{Materials and Method}

An AISI 304L stainless steel pipe with 1/2" (12,7 mm) thick and 12" (304, $8 \mathrm{~mm}$ ) of diameter was used as base material. As filler wire it was applied the AWS 309LSi 1,2 mm of diameter and pure Argon used as shielding and purging gas, to protect the weld seam. The cathode was a Tungsten electrode with 3,2 mm of diameter doped with $2 \%$ Cerium and sharpened with 40 . The electrode was sharpened with the same angle between each welding pass, in order to keep its emission integrity, although any contamination was observed during the welding. Table 1 shows the common parameters for all welding passes. The joint design was a " $U$ " profile as the dimensions shown in Figure 1. The orbital welding process used was the GTAW with dynamic wire feeding, which means a forward and backward movement applied in the wire feeder, as shown previously by Silva et al. [5]. In this case the wire's oscillation frequency was around $20 \mathrm{~Hz}$ and the hot wire technique was also used. The wire was inserted from behind to the arc. The welding steps by each layer (root and filling passes) consisted of two weld beads, starting at 12 $\mathrm{o}^{\prime}$ clock position and finishing at $6 \mathrm{o}^{\prime}$ clock (carried out in 180ㅇ of the pipe to complete the 360). In order to joining both passes, after each 180 o welding, at the end and the beginning it was made a preparation through grinding, facilitating the melting. The root pass welding was online monitored by a camera model HEMA ICAM Weld, which was fixed on the torch's body, enabling weld pool imaging along the entire circumference. The vertical down progression was adopted for better keyhole stabilization. Three samples were welded for replication. Finally, macrographic analyzes and X-ray tests, according to ASME Section- IX [22] requirements, were performed on the welded joints. The welded pipe was cut in 8 equal parts (at each 45) to enable the $x$-ray test and the equipment used was a model ERESCO $65 \mathrm{MF} 4$ Control, and the parameters were a voltage of $180 \mathrm{kV}$, current of $3 \mathrm{~mA}$ and exposure time of $54 \mathrm{~s}$.

Table 1. Parameters for all welding passes.

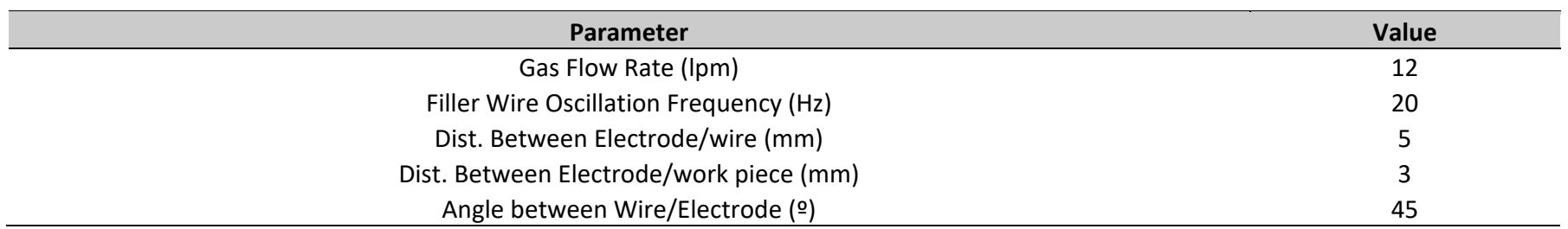



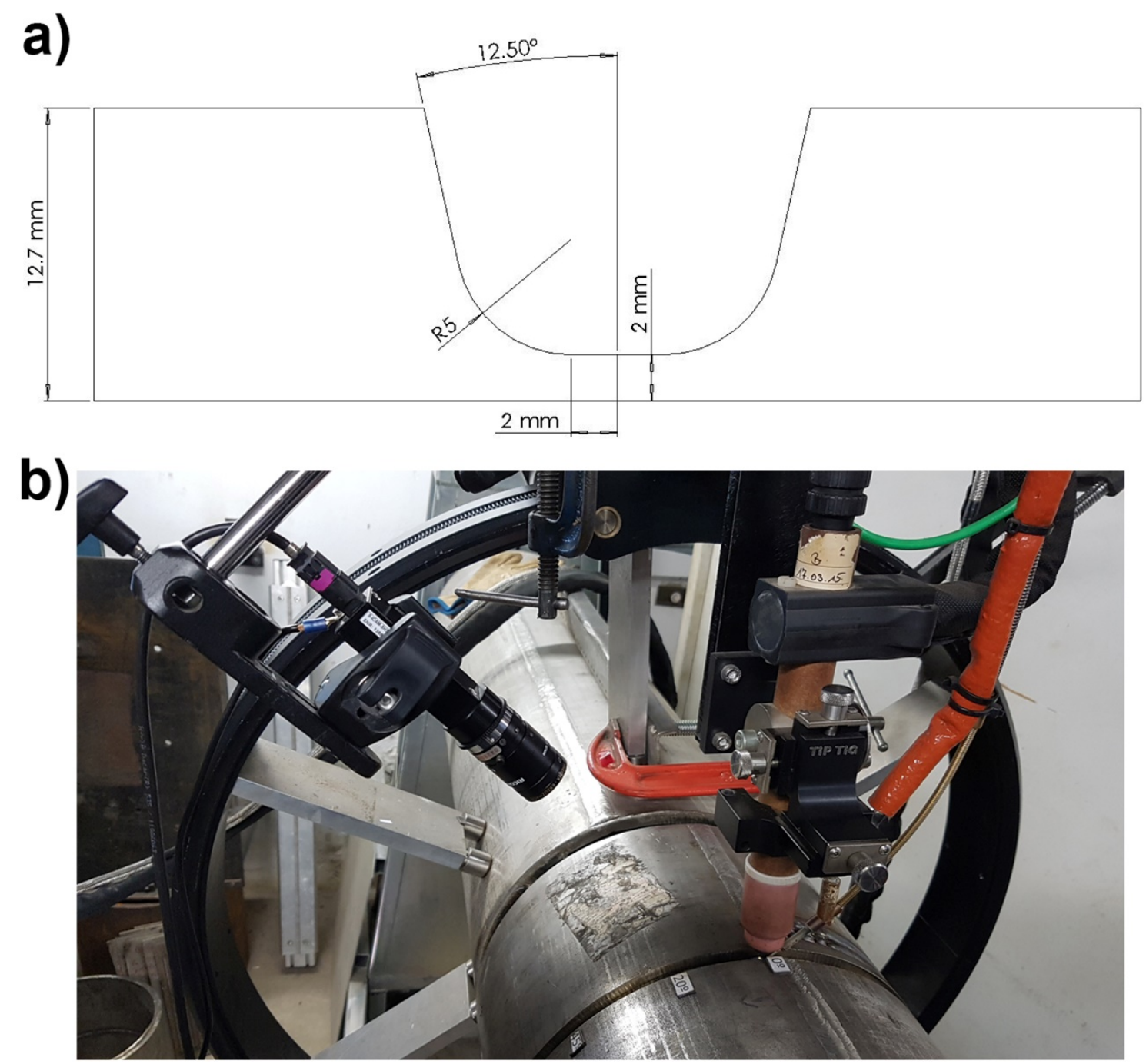

Figure 1. Joint Configuration and videography layout. In (a) Groove design; (b) Camera's position.

\section{Results and Discussion}

\subsection{Root pass}

To carry out the root pass, the main challenge was to deal with the variation of the melted material due to the variation of the welding position and forces acting over the process. These variations in the weld pool aspect were more critical on the root pass due to the necessity to keep the keyhole steadiness and avoid weld bead geometric changes, which can strongly affect the joint penetration with defects, as burn through or lack of fusion, and consequently a repair or the filling passes execution. The keyhole geometry and stability were only overcome by the welding parameters variation through the circumference. The parameters reached for each sector of the pipe, which was welded into two parts of 180, are shown in Table 2.

Table 2. Root pass parameters.

\begin{tabular}{|c|c|c|c|c|c|}
\hline \multicolumn{6}{|c|}{ Root pass } \\
\hline \multicolumn{2}{|c|}{ Sector range } & Current & Wire speed & Travel speed & Heat input \\
\hline 1 & $0-20$ & $290 \mathrm{~A}$ & $1.80 \mathrm{~m} / \mathrm{min}$ & $50 \mathrm{~cm} / \mathrm{min}$ & $0.26 \mathrm{~kJ} / \mathrm{mm}$ \\
\hline 2 & $20-160$ & $370 \mathrm{~A}$ & $1.50 \mathrm{~m} / \mathrm{min}$ & $50 \mathrm{~cm} / \mathrm{min}$ & $0.37 \mathrm{~kJ} / \mathrm{mm}$ \\
\hline 3 & $160-180^{\circ}$ & $300 \mathrm{~A}$ & $1.65 \mathrm{~m} / \mathrm{min}$ & $50 \mathrm{~cm} / \mathrm{min}$ & $0.28 \mathrm{~kJ} / \mathrm{mm}$ \\
\hline \multicolumn{6}{|c|}{ Torch weaving } \\
\hline Amplitude & $2 \mathrm{~mm}$ & Frequency & & ime & $0 \mathrm{~s}$ \\
\hline
\end{tabular}


With the parameter variation a stable condition was obtained in keyhole mode, this variation was possible due to a specific function available on the welding head, which enable the parametrization by sectors. The parameters changing occurs instantaneously, without stopping. Although the recognized difficult to stability it in the out of position welding, it was possible to reach process robustness just with constant current, albeit the welding position changes must be accurately identified. Assisted by the online videography, a strong change in the behavior of the keyhole was observed at the angles of 200 and 160 . These points were defined as the transition between the flat to vertical down position and the vertical down to overhead position, respectively. At 20 o position the keyhole tends to close quickly and the penetration becomes insufficient, creating lack of fusion points. On the other hand, at 160 o the keyhole enlarges strongly and the welding current must be reduced to avoid the burn through. Table 2 shows that the welding current is lower in the range of 0 o to 20 ㅇ (flat position) in which the penetration is assisted by the gravity force, together with the electromagnetic force. Then, once the 20 position is achieved, the molten pool begins to flow under the arc creating a barrier that hinds the keyhole maintenance, which tends to close quickly and the penetration becomes insufficient, creating lack of fusion point. Thus, there is a need to increase the intensity of the welding current, and consequently the arc's pressure over the pool. The filler wire's speed is also reduced, so the amount of arc's heat transferred to the wire is also lower and more heat is directed to melts the base metal. The dynamic wire feeding and its vibration can mitigating the defects generation, according to metallic transfer behavior discussed in other works [5-7]. In the overhead position (from 160 o 180) the behavior of the liquid material changes again, in this case was necessary to reduce the intensity of the welding current in order to avoid burn through, which would occur if it was kept at the same intensity as the vertical position. Although the gravity force vector acts contrary to penetration, the overhead position had a similar behavior to the flat position with very similar current intensity and wire speed parameters, although the wire speed has been slightly reduced to avoid excessive convexity on the face of the weld bead, identified in preliminary tests. Figure 2 shows the root pass cross section macrographs, which were taken from the indicated angles. The expected deeper profile is seen until 20ㅇ, while a flatter reinforcement inside the pipe is verified from vertical down until 180 o position.

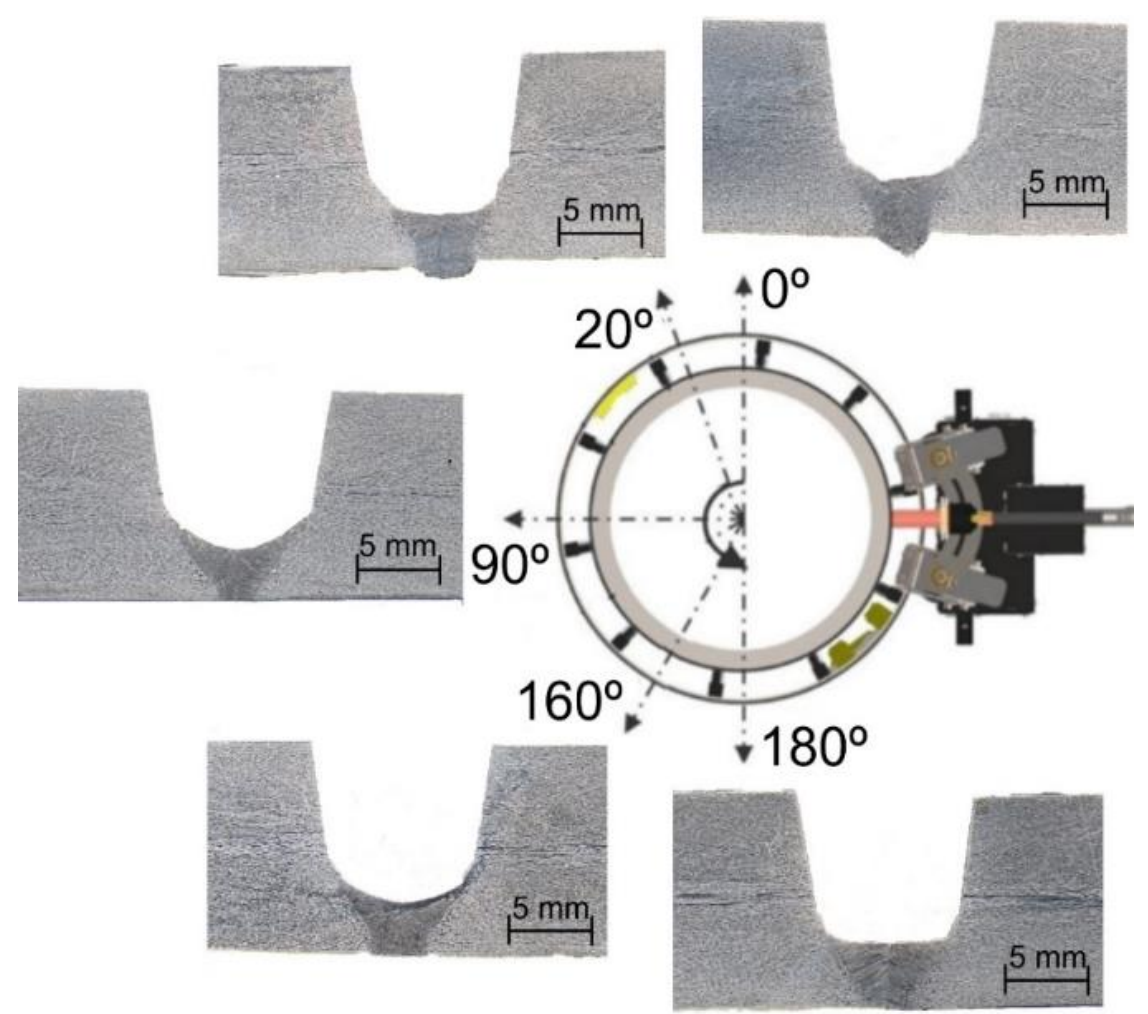

Figure 2. Micrographs of the root pass in different positions of the joint.

The entire aspect of the face and the inner root pass reinforcement are shown in Figure 3. There was an excellent wetting on the face of the weld bead, with no significant geometric difference along the pipe's circumference, as well as full penetration at all points. Even with the change in the parameters, the geometric aspect was kept similar, due to the change in the forces acting over the pool. It is also emphasized that was reached a slightly concave geometry on the root pass' face, satisfactory in preventing defects such as lack of fusion, in the deposit of the first filling pass. It is clear that special conditions and constraints must be developed and set in order to achieve a stable keyhole out of position. 


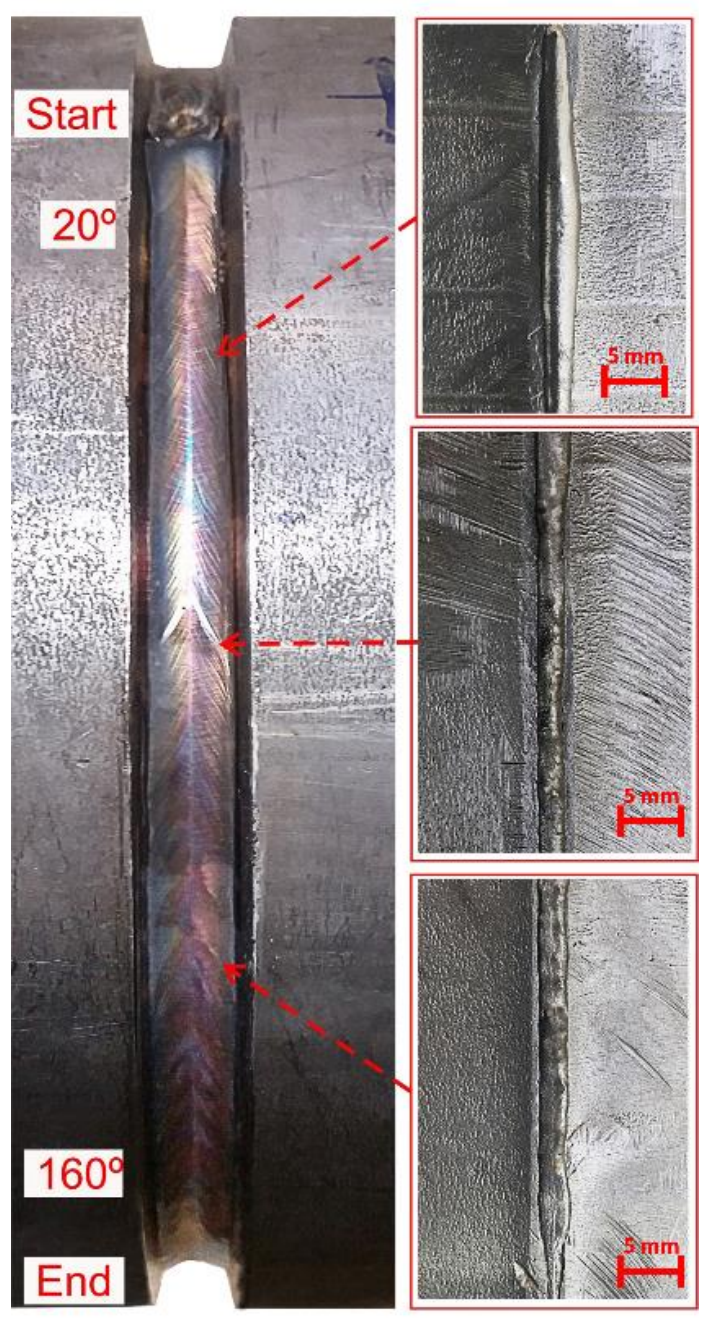

Figure 3. Surface and internal aspect of the root pass.

The online root pass videography which detach the cavity profile is shown by frames in Figure 4 . The insertion of the wire from behind the arc facilitated to reaches the keyhole condition, as it provides a direct attack from arc's fusion front to the base metal (indicated by the arrows in Figure 4). During the flat position (Figure 4a) a larger hole is verified when compared to the $20^{\circ}$ position (Figure $4 \mathrm{~b}$ ), where the hole tends to close and therefore the current is intensified to maintain the constant full penetration. During the vertical position (Figure 4c and Figure 4d) the keyhole is maintained. At 160ㅇ (Figure 4e) the current intensity is reduced and the hole maintains its size up to the 180 o position, in which it is closed with the application of a down slope in the current intensity until the arc off. 

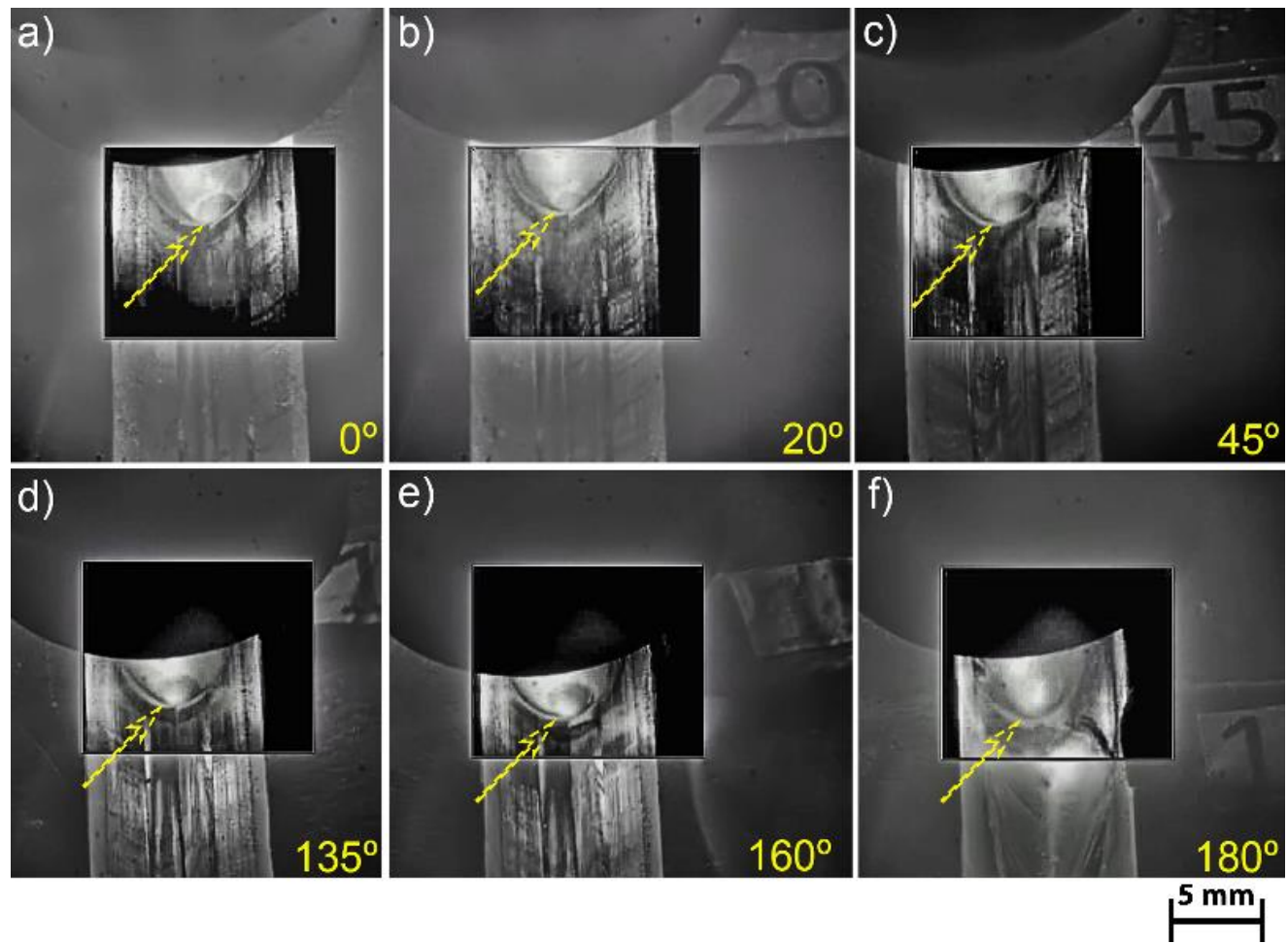

Figure 4. Keyhole aspect during the root pass along the pipe's circumference. In (a) 0o; (b) 20; (c) 45ㅇ; (d) 135o; (e) 160; (f) 180ㅇ.

The frontal videography of the keyhole profile hides the filler wire melting in the pool, so an efficient way to verify its regularity is by the welding voltage signal. Silva et al. [5] showed that the dynamic feeding promotes an oscillation in the voltage signal due to the wire's movement under the arc. Each peak oscillation in the voltage corresponds to a forward and backward event. Despite this, as detailed in the literature, it is possible to reach conditions in which the metallic transfer is through bridge mode (wire in constant contact with the molten material), depending on conduit layout, the forward and backward movement is not transferred to the wire's tip [5]. The Figure 5 shows a shortened version of the current and voltage signals behavior ( 2 seconds for each position) for all positions in the root welding. At the overhead, the voltage oscillated more than the other ones, at this point the wire breaks its constant contact with the weld pool and the metallic transfer becomes intermittent. In this situation, the dynamic feeding can assists the welding stability, because the wire's forward movement guarantees the touch between wire and melt pool, as exploited in another works [5-7].

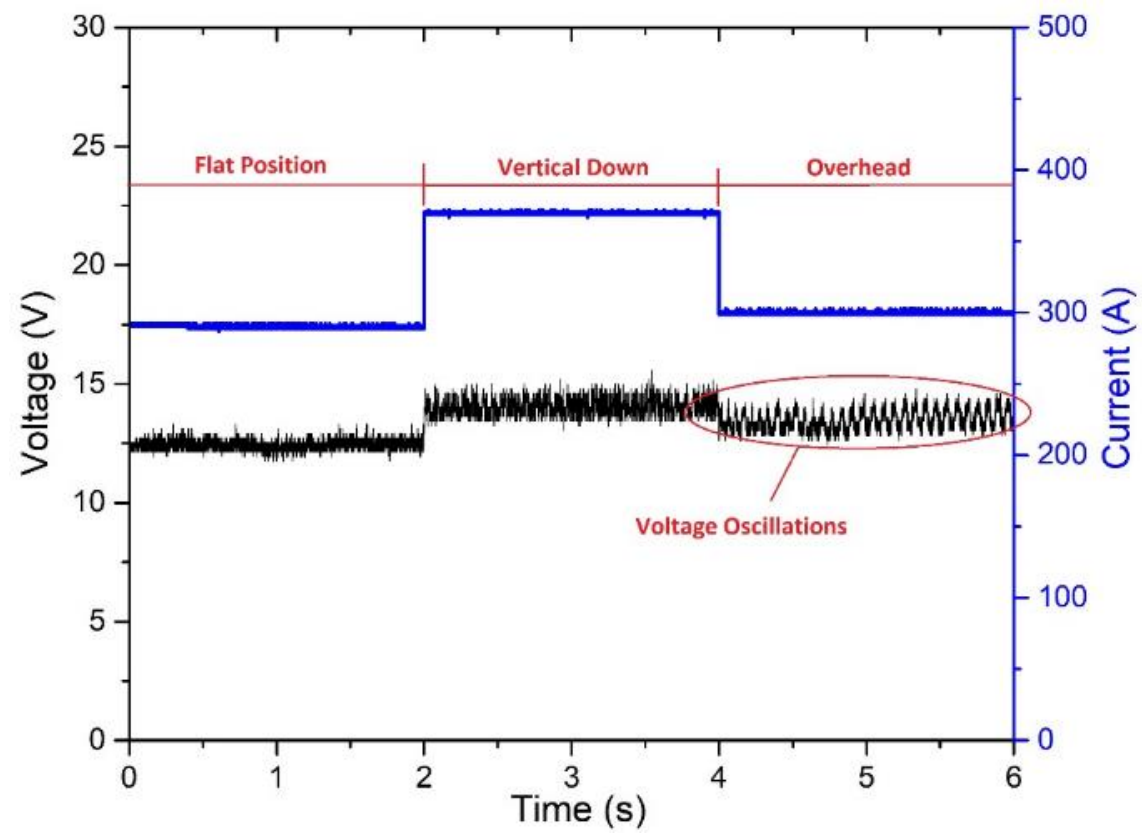

Figure 5. Current and voltage signals during the root pass along the pipe's circumference. 


\subsection{Filling and finishing passes}

The joint filling was divided into four filling passes and one finishing pass. The welding parameters for filling passes are shown in Table 3 and the parameters for finishing pass are shown in Table 4.

Table 3. Welding parameters for the four filing passes.

\begin{tabular}{|c|c|c|c|c|c|}
\hline \multicolumn{6}{|c|}{ Filling passes } \\
\hline \multicolumn{2}{|c|}{ Sector range } & \multirow{2}{*}{$\frac{\text { Current }}{250 \mathrm{~A}}$} & \multirow{2}{*}{$\begin{array}{l}\text { Wire speed } \\
1.80 \mathrm{~m} / \mathrm{min}\end{array}$} & \multirow{2}{*}{$\begin{array}{c}\text { Travel speed } \\
13 \mathrm{~cm} / \mathrm{min}\end{array}$} & \multirow{2}{*}{$\frac{\text { Heat input }}{0.83 \mathrm{~kJ} / \mathrm{mm}}$} \\
\hline 1 & $0-200$ & & & & \\
\hline 2 & $20-160$ & $250 \mathrm{~A}$ & $1.80 \mathrm{~m} / \mathrm{min}$ & $13 \mathrm{~cm} / \mathrm{min}$ & $0.83 \mathrm{~kJ} / \mathrm{mm}$ \\
\hline 3 & $160-180$ 은 & $250 \mathrm{~A}$ & $1.80 \mathrm{~m} / \mathrm{min}$ & $13 \mathrm{~cm} / \mathrm{min}$ & $0.83 \mathrm{~kJ} / \mathrm{mm}$ \\
\hline \multicolumn{6}{|c|}{ Torch weaving } \\
\hline Amplitude & $5 \mathrm{~mm}$ & Frequency & & ime & $0.5 \mathrm{~s}$ \\
\hline
\end{tabular}

Table 4. Welding parameters for the finishing pass.

\begin{tabular}{|c|c|c|c|c|c|}
\hline \multicolumn{6}{|c|}{ Finishing pass } \\
\hline \multicolumn{2}{|c|}{ Sector range } & \multirow{2}{*}{$\frac{\text { Current }}{200 \mathrm{~A}}$} & \multirow{2}{*}{$\begin{array}{l}\text { Wire speed } \\
0.85 \mathrm{~m} / \mathrm{min}\end{array}$} & \multirow{2}{*}{$\begin{array}{c}\text { Travel speed } \\
9 \mathrm{~cm} / \mathrm{min}\end{array}$} & \multirow{2}{*}{$\frac{\text { Heat input }}{0.88 \mathrm{~kJ} / \mathrm{mm}}$} \\
\hline 1 & $0-200$ & & & & \\
\hline 2 & $20-160$ 은 & $200 \mathrm{~A}$ & $0.85 \mathrm{~m} / \mathrm{min}$ & $9 \mathrm{~cm} / \mathrm{min}$ & $0.88 \mathrm{~kJ} / \mathrm{mm}$ \\
\hline 3 & $160-180^{\circ}$ & $200 \mathrm{~A}$ & $0.85 \mathrm{~m} / \mathrm{min}$ & $9 \mathrm{~cm} / \mathrm{min}$ & $0.88 \mathrm{~kJ} / \mathrm{mm}$ \\
\hline \multicolumn{6}{|c|}{ Torch weaving } \\
\hline Amplitude & $14 \mathrm{~mm}$ & Frequency & & me & $0.8 \mathrm{~s}$ \\
\hline
\end{tabular}

In theory, the realization of the filling passes has lower difficulty when compared to the root pass. However, alloying elements such as chromium, present in the base material (304L) and in the filler metal (309LSi), besides molybdenum present only in the wire, provide less wettability to the weld pool, creating a situation favorable to defects, as lack of fusion on the groove's side and between passes. Both filling and finishing passes, carried out on lower speed when compared to the root pass, the welding current had no changes in its value along the pipe's circumference. For the filling passes it was obtained a good weld bead spreading, applying $5 \mathrm{~mm}$ in the torch's oscillation amplitude. It is important to verify that the "U" groove profile used in this work has narrow gap characteristics. Therefore, this profile, aims to increase productivity by reducing the amount of material (groove's area) needed to fill the joint, although it is a profile that limits the lateral torch movements. In the final finishing pass, an increase in the torch's oscillation amplitude was allowed, which was increased to $14 \mathrm{~mm}$, since the electrode is no longer inside the groove, resulting in a condition similar to a deposition over the pipe surface. This greater amplitude allowed a larger weld bead spreading, generating an excellent superficial aspect. It is important to note that the purge gas was maintained during the entire joint welding, because the high temperature reached inside the pipe, until the end of the finishing pass in conjunction to the presence of oxygen, generates the formation of oxides that reduce strongly the weld mechanical resistance and corrosion resistance. Figure 6 shows the aspect of all filling passes until the finalization of the joint. 


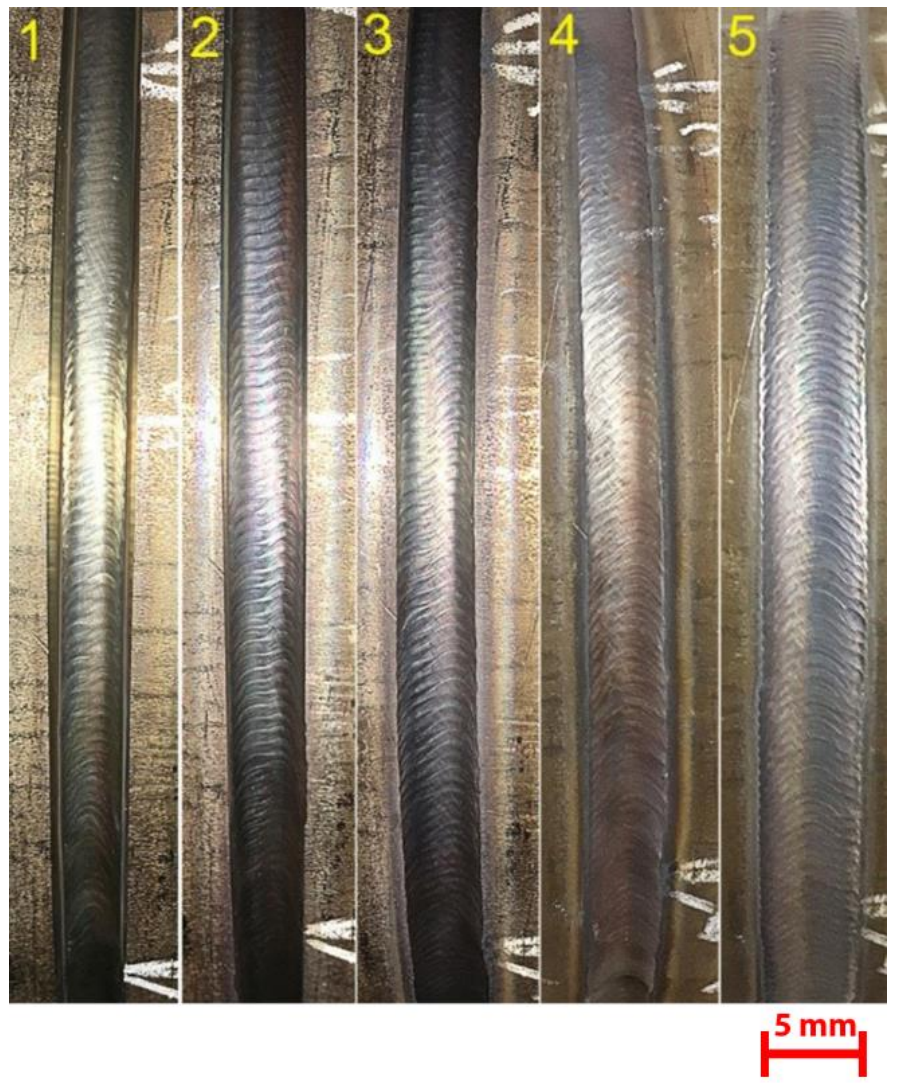

Figure 6. Superficial aspects of filling passes e finishing pass. The numbers from 1 to 5 means the sequence of welding passes.

The filled joint macrographs correlated with its circumference position are shown in Figure 7. No macroscopic discontinuities were found and the penetration was satisfactory, repeating the results showed in Figure 2.

Comparing the welding procedure developed in this work versus another orbital technique, as presented by Pigozzo [23] and Chowdary et al. [24] both using the GTAW with continuous feeding for the root pass. The authors reached averages of $10 \mathrm{~cm} / \mathrm{min}$ and $5,6 \mathrm{~cm} / \mathrm{min}$ respectively, while in the keyhole mode presented here was possible $50 \mathrm{~cm} / \mathrm{min}$.

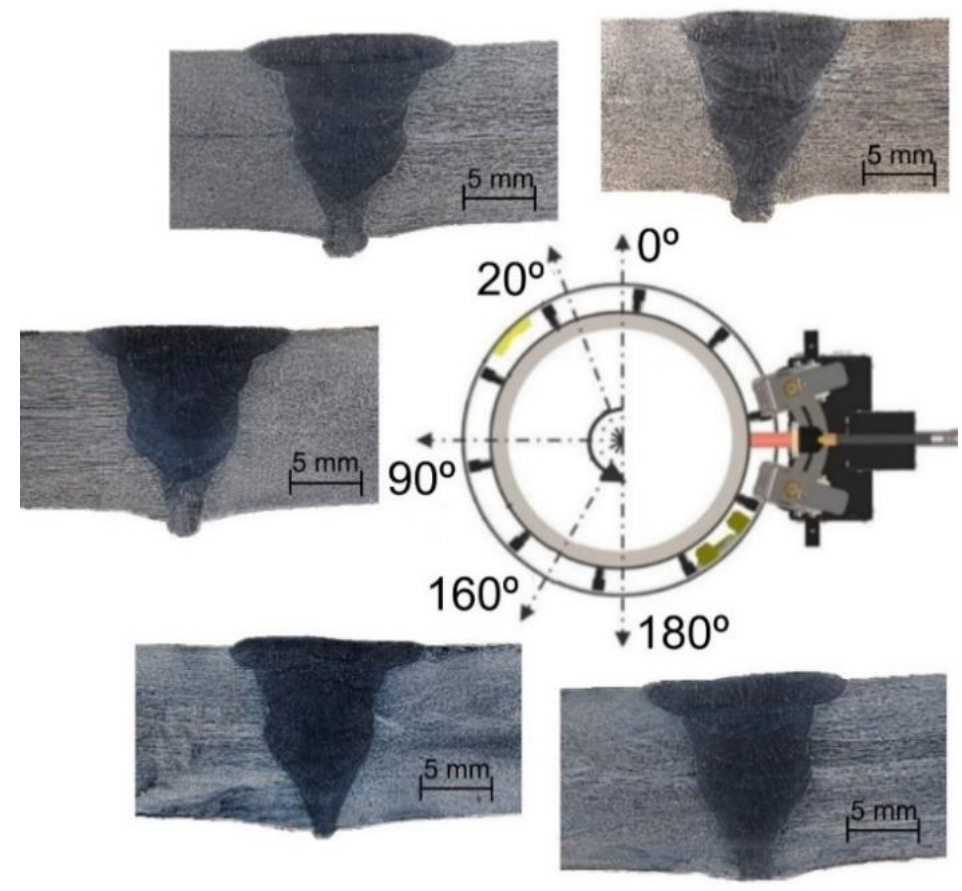

Figure 7. Macrographs of the complete joint in different joint positions. 
In the X-ray inspection, images were obtained from specific regions along the entire pipe's circumference, as shown in Figure 8. No weld defects were identified along the weld length as well as in the thickness of the weld bead. Figure 7 also shows the root pass (lighter region, that absorbed more gamma rays) as indicated by the arrows. In the root pass, points with a slightly higher penetration were observed, as highlighted by the lighter regions, which can also be macrographically visualized in Figure 3. Also, the entire weld bead thickness and the finishing pass's edge can be seen, and both appear without defects.

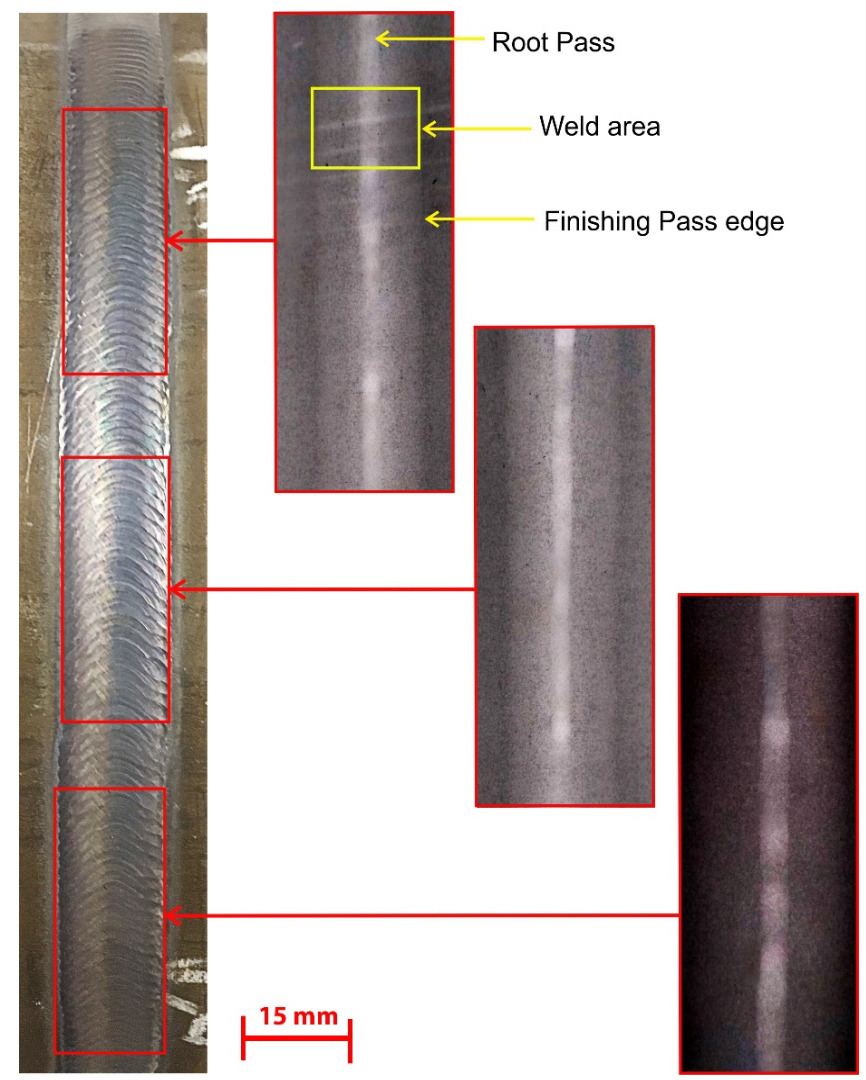

Figure 8. Weld joint analysis by X-ray test.

\section{Conclusions}

The importance in the joining of stainless steel pipes is recognized in the oil and gas industry. Therefore, this work fills an important gap in the search for the automation in the circumferential welding steps pipes, showing that it is possible to combine both characteristics: productivity and quality in the spool fabrication process.

The keyhole technique was successfully joined with the dynamic wire feeding technique, providing a method and procedure for obtaining defect free, full penetration root and fill passes, as proven by macrographic and $\mathrm{x}$-ray tests. Another positive and distinguishing aspect attained in the root pass was the high travel speed reached, of about $50 \mathrm{~cm} / \mathrm{min}$.

The dynamic wire feeding assisted all welding steps, from the root to the finishing pass. Although providing stability over the entire weld, its distinguishing effect is highlighted in the overhead position, where an otherwise constant speed wire feed would tend to result in electrode contamination by large wire droplets formed on the wire's tip. The forward and backward wire movement results in a robust, repeatable and reliable small droplet transfer, mitigating process instabilities.

The automated procedure developed in this work can assists the welders providing healthier and ergonomic working environments, in addition to the possibility of productivity increase, since it carries out the welding with higher speeds when compared to a convention and manual GTAW welding. The main constrains related to the application of this procedure in a real environment are related to the quality in the joint's assembly and fabrication. This both points are crucial for an automated welding procedure.

\section{Acknowledgements}

The authors would like to acknowledge the Petrobras and CNPq for financial support in addition to IMC and LABSOLDA's staff for technical support. 


\section{References}

[1] Richardson M. Semiautomatic cold wire feeder systems increase GTA productivity. Welding Journal. 1995;74:51-54.

[2] Ouyang JH, Wang H, Kovacevic R. Rapid prototyping of 5356-aluminum alloy based on variable polarity gas tungsten arc welding: process control and microstructure. Materials and Manufacturing Processes. 2002;17(1):103-124. http://dx.doi.org/10.1081/AMP120002801.

[3] Hori K, Watanabe H, Myoga T, Kusano K. Development of hot wire tig welding methods using pulsed current to heat filler wire-research on pulse heated hot wire tig welding processes. Welding International. 2004;18(6):456-468. http://dx.doi.org/10.1533/wint.2004.3281.

[4] Anantha PMR, Baskar N, Devakumaran K. A study on process characteristics and performance of hot wire gas tungsten arc welding process for high temperature materials. Materials Research. 2017;20:76-87. http://dx.doi.org/10.1590/1980-5373-mr-2016-0321.

[5] Silva RHG, Riffel KC, Okuyama MP, Dalpiaz G. Effect of dynamic wire in the GTAW process. Journal of Materials Processing Technology. 2019;269:91-101. http://dx.doi.org/10.1016/j.jmatprotec.2019.01.033.

[6] Silva RHG, Paes LES, Okuyama MP, Sousa GL, Viviani AB, Cirino LM, et al. TIG welding process with dynamic feeding: a characterization approach. International Journal of Advanced Manufacturing Technology. 2018;96(9-12):4467-4475. http://dx.doi.org/10.1007/s00170018-1929-6.

[7] Riffel KC. Avanços tecnológicos do processo TIG: técnicas inovadoras de alimentação de arame e procedimentos automatizados como contribuição para a união de tubos internamente cladeados [dissertação de mestrado]. Florianópolis: Universidade Federal de Santa Catarina; 2018.

[8] Silva RHG, Paes LES, Marques C, Riffel KC, Schwedersky MB. Performing higher speeds with dynamic feeding gas tungsten arc welding (GTAW) for pipeline applications. Journal of the Brazilian Society of Mechanical Sciences and Engineering. 2019;41(1):38. http://dx.doi.org/10.1007/s40430-018-1529-2.

[9] Silwal B, Santangelo M. Effect of vibration and hot-wire Gas Tungsten Arc (GTA) on the geometric shape. Journal of Materials Processing Technology. 2018;251:138-145. http://dx.doi.org/10.1016/j.jmatprotec.2017.08.010.

[10] Chen S, Zhang S, Huang N, Zhang P, Han J. Droplet transfer in arcing-wire GTAW. Journal of Manufacturing Processes. 2016;23:149-156. http://dx.doi.org/10.1016/j.jmapro.2016.05.014.

[11] Lathabai S, Jarvis BL, Barton KJ. Comparison of keyhole and conventional gas tungsten arc welds in commercially pure titanium. Materials Science and Engineering A. 2001;299(1-2):81-93. http://dx.doi.org/10.1016/S0921-5093(00)01408-8.

[12] Scotti A, Reis RP. Fundamentals and practice of plasma welding. São Paulo: Artliber; 2007.

[13] Jarvis BL, Ahmed NU. Development of keyhole mode gas tungsten arc welding process. Science and Technology of Welding and Joining. 2000;5(1):21-1718. http://dx.doi.org/10.1179/136217100322910624.

[14] Schwedersky MB, Dutra JC, Okuyama MP, Silva RHG. High productivity TIG welding: influence of shielding gases on the limiting speed for formation of defects. Soldagem e Inspeção. 2011;16(4):333-340. http://dx.doi.org/10.1590/S0104-92242011000400004.

[15] Olivares EAG, Silva RHG, Dutra JC. Study of keyhole TIG welding by comparative analysis of two high-productivity torches for joining medium-thickness carbon steel plates. Welding International. 2017;31(5):337-347. http://dx.doi.org/10.1080/09507116.2016.1218603.

[16] Li XR, Shao Z, Zhang YM. Double stage plasma arc pipe welding process. Welding Journal. 2012;(91):346-353.

[17] Shirali AA, Mills KC. The effect of welding parameters on penetration in GTA welds. Welding Journal. 1991;72:347s-353s.

[18] Figueirôa DW, Pigozzo IO, Silva RHG, Santos TFA, Urtiga SL Fo. Influence of welding position and parameters in orbital tig welding applied to low-carbon steel pipes. Weld Int. 2017;31(8):583-590. http://dx.doi.org/10.1080/09507116.2016.1218615.

[19] Kou S, Wang TH. Weld pool convection and its effect. Welding Research. 1986;65(Suppl): 63-70.

[20] Xiao F, Yang R, Zhang C. Surface tension of molten Ni-W and Ni-Cr alloys. Materials Science and Engineering B. 2006;132(1-2):183-186. http://dx.doi.org/10.1016/j.mseb.2006.02.017.

[21] Shipilov AV, Erofeev VA, Poloskov SI. Determination of the optimum conditions of melting of filler wire in automatic orbital welding of steel pipes. Welding International. 2013;27(5):397-402. http://dx.doi.org/10.1080/09507116.2012.715924.

[22] American Society of Mechanical Engineers - ASME. BPVC section IX-welding, brazing, and fusing qualifications. New York: ASME; 2019 [acesso em 7 maio 2019]. Disponível em: https://www.asme.org/products/codes-standards/bpvcix-2019-bpvc-section-ixweldingbrazing-fusing

[23] Pigozzo IO. Soldagem TIG orbital: otimização de equipamentos e prospecções tecnológicas para procedimentos de passe de raiz [dissertação de mestrado]. Florianópolis: Universidade Federal de Santa Catarina; 2014.

[24] Chowdary BV, Maharaj RR, Lewis WG. development of welding parameters to perform root pass welding using a mechanized GTAW process: a case study. The West Indian Journal of Engineering. 2010;32:20-27. 